\title{
Impact of Cultural Value System on the Personality Development of Ogoni Adolescents
}

\author{
Mary Basil Nwoke, PhD \\ Department of Psychology, University of Nigeria, Nsukka 41000, Enugu State, Nigeria \\ E-mail: mbnwokeddl@yahoo.com
}

Received: August 1, 2011

doi:10.5539/ass.v8n3p100
Accepted: November 17, $2011 \quad$ Published: March 1, 2012

URL: http://dx.doi.org/10.5539/ass.v8n3p100

\begin{abstract}
Cultural value system is a very important and significant issue in the life of Ogonis in Nigeria. This is because it is the compendium of their entire life. In this study the first of its kind, the process of ethnic identity formation among the Ogoni adolescents is explored. Sixteen participants (8males and 8 females) completed the semi structured interviews and the qualitative data collected was analysed using a grounded theory approach. Based on the findings of this study, a preliminary understanding of the impact of cultural value system on the personality development among the Ogoni adolescents is presented and discussed in detail. The qualitative interviews unveiled the presence of compulsory rite of passage into man/womanhood called 'koo' and 'yaa' which every Ogoni adolescent boy or girl must partake. Finally through a thematic analysis, cultural values like 'sira-culture', 'masquerade-cult' and 'were-beast-affinity' that impact on the personality of Ogoni adolescents were uncovered.
\end{abstract}

Keywords: Culture, Values system, Adolescents, Personality, Ogoni

\section{Introduction}

Etymologically value system is embedded in the culture of the people. Culture is a set of shared values, beliefs, attributes, customs and physical objects that are maintained by people in a specific setting as part of a design for living one's daily life. Cultural value systems of any group of people are passed on from generation to generation through child-rearing practices (Phinney\& Alipura, 1990). Havilland (1983) stated that culture consists of abstract values, beliefs and perceptions of the world that lie behind people's behaviour and that which that behaviour reflects. The long judgment to which culture is subjected enhances its internalization. This assertion is confirmed by Tschumi (1978 in Nwideeduh,1998), who observed that 'culture is not simply left to the whims of major opinion, on the contrary it is submitted to a judgment which is formed slowly, carefully and rigorously.

There are various ways in which culture and the value system could have an impact on the personality of an individual and his/her modes of lifestyle and adjustment. Schrest and Wallace (1967) observed that culture and personality are two ways of looking at the same phenomenon. Certainly an individual's personality is the end product of an interaction between biological and experiential factors and experiential factors are culturally determined. The most evident source of cultural value system's influence on personality is by way of childrearing orientations that are culturally conditioned. Haralambos \& Heald (1980) stated that 'for all intents and purposes, a new human baby is helpless, not only is it physically dependent on older members of the species, but it also lacks the behaviour patterns necessary for living in human society. It relies primarily on the charity of its elders to satisfy those drives. In order to survive, the infant must learn the skills, knowledge and accepted ways of behaving of the society into which it is born' (p. 3). So in all ramifications cultural value system has a lot to account for in the intellectual, social, emotional and cognitive development and adjustment, which make up the total personality of the human being. Chukwuagguh (1998) observed that the hidden aspects of a culture which comprises beliefs, ideas, values, assumptions and modes of thought which members of a group adhere to are covertly transmitted or inculcated in generations of offspring. This governs not only the behaviour of the group, but also their socio-cognitive view in a profound manner. It is therefore certain that the information derived from cultural value system enables the individual to adapt effectively to his/her environment. In this sense, it can be stated that an adolescent's personality formation depends on his/her adjustive capacity to his/her cultural demands. 
In traditional societies with no formal education, the personality development and adjustment of adolescents are tested on those values with which people from their ethnic groups are identified. The psychological concept of personality development and adjustment explains the teenager's struggles to identify himself or herself with his/her ethnic group's way of life or behaviour. It also explains the struggle to survive as the teenager interacts with his/her social and physical environments. Schrest and Wallace (1967) observed that cultural heritage is deeply imbedded that people's cultural determined way of doing things and out look on life seems natural and right in comparison with other peoples. They saw that there are various ways in which culture might have an impact on the personality of an individual. Every culture provides both prescriptions and proscriptions for behavioural patterns. Systems of reward and sanctions are very often specified. Thus certain forms of lifestyle are prescribed and even rewarded, while other forms may be forbidden and punished. Furthermore, Schrest and Wallace (1967) indicated that every culture provides its members with a socio-cognitive structure from within which they will review and try to make sense out of through their experiences. Ephraim (1994, Santrock, 2006) observed that one does not only follow a given value because of the prospect of certain rewards or sanctions, but also follows those value systems or patterns of behaviours which have salience within the cultural context. The teenager's behaviours, which are components of value systems, are critical in establishing his/her socio-cognitive world view, on which he/she would base life's achievement pattern

Nigeria is a country with diversified cultural backgrounds with its multi-ethnic groups. Ethnic group is cultural heritage, nationality characteristics, race, religion and language. Ethnicity is central to the development of an ethnic identity, which is the sense of membership based on the shared language, religion, customs, values, history and race, (Chukwuagguh, 1998). Dibiah (1988) attested that ethnicity is a variable of importance on how people cope or adjust with situations or environments. The multiplicity of languages and dialects certainly contributed to the profound ethnicity in Nigeria. Benton (1969 as in Nwideeduh 1998), observed that effective communication between tribal groups is hindered by the 200 or more dialects spoken. Every human being is identified with an ethnic group and the diversities of value system. This study investigates the impact of cultural value system on the personality development of Ogoni adolescents.

\subsection{The Ogoni People}

Ogoni is an ethnic group in the Niger Delta region, in Nigeria, located in the southern part of Nigeria. The Niger Delta is inhabited by some 1,600 long settled communities. Loolo (1981) observed that most historians of the Niger Delta area agree that the area was peopled by three distinct waves of migrants from tribal hinterland, and different parts of Africa. The earliest settlers, the Ijaws appear to have preceded the advent of the Portuguese. The most important movement of population in the Niger Delta region occurred between 1450 and 1800 and gradually converted the little fishing villages into city states. This was the second wave of migrations and the tribes stretched from the coast to the hinterland and this followed the development of slave trade. It was during this era of traffic in human beings that the Delta gained the bulk of her population. The British government's decision to abolish slave trade in 1807 and the activities of the British Navy in the Delta resulted in a medley in the coastal area.

Loolo (1981) further expressed that the absence of records and insufficient anthropological studies of the tribe had up till recently shrouded the origins of the Ogoni in mystery. However, recent studies and oblique references in search works by other scholars show that the Ogoni were one of the earliest settlers in the area now known as the Niger Delta region. Some people have claimed that the Ogoni originated some where in the East, possibly in the southern half of Nigeria - Cameroun board area, (Mbiti, 1969). Others have alleged that the Ogoni originated from the hinterland, (Nwideeduh, 1975). But loolo (1981) suggests that the Ogoni might have originated from Ghana by accident during the thriving trade in slaves. He stated that oral tradition has it that a fleet of soldiers of fortune from that area set sail for slave trade along the Nigerian coast; but got stranded at the estuary of Imo River, at the place currently known as Opuoko. Then fearing the activities of the British Navy, they decided to make their home there rather than risk capture by the British anti-slave trade navy. Historians of this school of tradition contend that the name of the people of this area, Khana, was actually, a mistaken pronunciation of the word Ghana. The evidencse of Ghana origin can easily be further found in type of major crops cultivated by the Khana and some other behavioural patterns in the farms, which are typical of Ghana.

With the creation of states in Nigeria, Ogoniland is presently located in the Rivers State of Nigeria. The area occupied by the Ogoni lies approximately between latitude $4.05^{`}$ and longitude $7.308^{`}$ East. It is bounded on the west by the Ikwere of Rumukrushe on the north and east by the Imo River and on the south by the Andoni, covering about 404 square kilometres, it forms part of the coastal plain terrace which appears at a gently sloping plateau intersected by a few deep valleys which carry water intermittently. The central part of this plateau is about one hundred feet above sea level. Alagoa (1972) observed that the language of the Ogoni is like that of 
Ogbia, but Loolo (1981) indicated that there has always been resentment among some members of the tribe against the name Ogoni, partly because it has been used as a contemptuous appellation by some Nigerians. For example, at various times in history the Ogoni people had been called either cannibals or savages because of their ferocity. There are six clans and one hundred and eleven villages in Ogoniland, spreading among the six clans that make up the stock. The clan are Babbe, Gokhana, Ken, Nyokhana, Eleme and Tai. There is one Ogoni community that has been politically lumped with the Annang area. This community is Wsisues or Warifes with their cultural linguistic and social links with the stock, (Alagoa, 1972; Loolo, 1981; Akassa, 1998). Each of these six clans has her own market day; which is usually held in the mornings when people from other towns come and buy goods or in the evenings, when people have returned from their farms. At the markets articles were battered in exchange, but now the transaction is purely on cash basis.

Evaluating the impact of cultural value system in Ogoniland, Nwideeduh (1998) observed that the Ogoni, as a distinct ethnic group located in the mainland fringe bordering the Eastern Niger Delta of Rivers state, have been grossly affected by her culture in the pursuit of educational development over the years. He indicated that the isolation of the Ogoni from other ethnic groups in the Eastern Niger Delta of Nigeria, especially those located at Opobo, Okrika and others during the colonial days was caused by the monopolistic tendencies of the middlemen. In support of this assertion, Gbenenye (1998) observed that despite the common trade links between the Ogoni and other ethnic groups, it was impossible for them to travel beyond the designated market. One of the major characters involved in the oil Rivers protectorate was King Jaja of Opobo, who almost colonized the whole territory by 1884. Jaja's monopoly was so severe that as close as Kono, Buan, Kwawa, Eweh, Bane, Bean and Kpean villages were to Opobo, they could not have direct access to British traders. In a similar vein, Kpone-Tonwe (1990), succinctly described the economic, social and political decline of the Ogoni by the end of the period of legitimate trade that is the beginning of the colonial period, thus: "The eclipse of Ogoni from the outside world continued unabated into the colonial period. Ogoni with her agricultural resources became the private preserve of her coastal neighbours. But the colonial agents and missionaries were not aware of the internal conditions of the Ogoni” (p.298). It was observed that as long as the people enjoyed their fertile land for farming and streams and rivers for their fishing, access roads which the favourable soil provide, they had no reason to complain about their isolation from the outside world. The communities were so intact and indomitable that they constituted a formidable force against any external aggression (Obi, 1997, UNPO, 1995, This Day, 2005). Nwideeduh (1975) observed that the long seclusion of Ogoni from the outside world, made them appreciate their culture more especially as it affected their magic, charm and folklore and other value systems.

\subsection{Ogoni value systems include}

Rite of passage into manhood and womanhood. 'yaa' and 'koo'

'Sira-culture'.

'Were beast affinity'.

Masquerade cult-value

\subsection{Social Customs}

There are two principal types of marriage among the Ogoni namely, the dowry marriage and concubinage (Andah, 1982, 1988, Loolo, 1981). There is another type of marriage, where a little ritual token is paid. This type of marriage as Loolo 1981, Egonwa, 1994) observed, it is the usual custom in Ogoniland that if a woman gives birth to a lone female child, she would not be given out in marriage for which bride price would be paid. However, any man who fancies her, would approach the parents, perform the customary value rites and live with her as husband and wife. The difference between this type of marriage and the one for which one pays bride price is that when the children of the association grow-up to manhood or womanhood, they return to the home of their mother's parents and identify the father's name, by answering the name. The man who begot those children, meaning the biological father goes childless and none of the children will identify with the biological father's name no matter what they might become in future and their positions in the world, they are not recognised in their biological father's home. The other type of marriage is the one involving payment of bride price. This is usually on arrangement between the parents of both the bride and the bridegroom. Like many ethnic groups in Nigeria, this type of marriage involves a lot of protocol among the Ogonis. Before the invention or introduction of British currency, pounds and shillings, bride price was paid in manilla. It was said that the whole amount was never paid at the same time. Polygamy is universal among the Ogoni and was greatly approved by the women. A man's status in the society was sometimes judged by the number of his wives and extent of his yam farm. One of the major reasons for marrying many wives was to help in the farms. There is no limit to the number of wives a man could marry it depended on the strength of the man's purse and inclination. There is a ceremony of coming 
of age (initiation) that the Ogoni man or woman must perform before he/she can speak or have a say at public meetings or gatherings in the village. This ceremony is called "yaa" for males and "koo" for females. This initiation takes place from the age of 10 (pre-pubertal age) to 25 years. The participants are gathered and confined for three months in a fatting room. During this period they go through different initiation rites as laid down by tradition. At this period these Ogoni human beings are usually termed 'sacred', at the end of the confinement, the participants also perform some public activities or rituals in the city or village square, usually conducted in huts made of palm branches and were called "Tor-wii". This public ritual ordeal or activity proves that the individual is now a "man or woman". All these cultural values are prominent till date and children within the age bracket of 10-25 years are subjected to them, (Nwideeduh, 1975, Andah, 1982, 1988, Alagoa, 1972, Loolo, 1981).

Research evidence on affinities (Alagoa, 1972, Nwideeduh, 1998) show that the Ogoni are matrilineal, that is children belong to the affinities of their mother and not of their father. Nearly all strong animals in the bush, such as tiger, elephants, antelopes, tortoise, and aquatic animals such as crocodiles, turtles and catfish are credited as being "were- beast", which signifies affinity. The idea that the soul of man or woman has the power to leave its human form and enter into that of its affinity, or appear in the shapes of the "were-beast" is firmly held among the Ogoni. It is strongly believed that if any thing happened to the affined beast, it will certainly affect the human being whose soul or spirit is affined in the "were-beast". This cultural value is inculcated to the members of the group during child rearing practices and consolidated during the confinement period of "yaa" and "koo" initiation. It is during the three months' confinement that a lot of other cultural values are reviewed, initiated and confirmed in the adolescents.

\subsection{Occupation}

The main occupation of the Ogoni is farming and work on the farm is clearly defined. The men cut the big bush, make the heaps for yam, collect the stick or props, canes and strings for fastening or staking the tendrils. They construct the tracks in which the yam seeds and tubers are stored. The women cut the yam into required sizes, organize the planting of the yam and other crops on the farm. They weed the farm at regular intervals until harvest season. Another occupation allied to farming is hunting, which is carried out by men skilled in the art. Fishing is a popular and full time occupation for those villages are on the creeks and along the Imo River Basin. Canoe carving is a special skill practiced by men in certain communities of Ogoni, the Opnoko and in Kalaoko. Pottery is practiced in the areas where suitable clay is found usually it is the women who are potters. It is important to note that in Ogoniland, every child is introduced or initiated into farm work and the allied occupations at the age of five even though he/she could not do the actual farm work or allied works meant for an adult. He/she is put in the line of thought and behaviour expected of his/her gender. At this stage it could be adduced that the child is conditioned to socio-cognitive learning. Before the individual reaches teenage, he/she is already used to the way of thinking, reasoning, interpreting, assessing or evaluating the quality of the soil and its content in terms of fertility for a rich harvest. The language and tactics with which prominence is achieved in Ogoniland are communicated to the child, who uses them as a yard stick in his/her line of thought, thereby developing an insight into what his/her future would be.

Without mincing words the Ogonis are an agricultural and fishing society. Yam and cassava farming are important ways of making a living, although the revenues of these products are not very high. The most important export product of Nigeria is oil and Ogoni is 'the oil well' of the nation, but the Ogoni people have never profited from these exports. Once the 'food basket' for the Niger Delta and beyond, Ogoniland's agricultural production has now been severely reduced. This is partly due to loss of farmlands through oil pollution and partly to soil fertility problems arising from acid/alkaline rain caused by gas flaring. Large areas of fresh and salt water resources as fishing grounds have also been rendered useless by oil spills. Food is becoming increasingly expensive and potential farmers are too poor to pay for seeds and labour. Poverty has worsened in the Ogoni areas during the recent years. Nearly all oil workers are people coming from outside Ogoni and the local people had to compete with them for basic commodities. Besides the oil installations and refineries there are no manufacturing industries in Ogoni to reduce unemployment. This situation increasingly results in psycho-social degradation and agitation especially among the youngsters (Joshua, 2009).

\subsection{Objective of the current study}

The primary purpose of this exploratory study which is the first of its kind is to examine the impact of cultural value system on the personality development of Ogoni adolescents. The secondary objective of this study is to investigate if cultural value has impacted on the educational development of the Ogonis. Thirdly to examine the impact of modernity on Ogoni cultural value system. 


\section{Method}

\subsection{Participants}

The data collection was part of a larger 7-year study on the effects of ethnic group, age and gender differences on the bio-socio- cognitive adjustment among teenagers in Nigeria (Nwoke 2004), from which this current study focuses exclusively on the impact of cultural value system on the personality development of Ogoni adolescents. Specifically 16 Ogoni adolescents ( 8 males and 8 females), age brackets: Junior adolescents 13-15 years, with a mean age of 14years, Senior adolescents 16- 18 years, with a mean age of 17 years, and late adolescents (early adults -youth) age,20-25years, with a mean of 22.5 years. This choice is because 13-25 years are the group usually involved in the initiation of 'koo' and 'yaa' rites of passage. For the sake of clarity, the junior adolescents comprise ( 3 males and 3 females), senior adolescents comprise ( 3 males and 3 females) and the youth are ( 2 males and 2 females) The reason for involving the youth in the interview is because age 20-25 have been initiated into the value system and can explain the impact of it on their personality development.

For the sake of confidentiality, real names of the participants are withheld. The researcher got to various secondary schools with the help of research assistants and a snow balling method was used to recruit the 16 participants. The age ranged from 13 to 25 years. Table 1 provides a brief description of each of the participant. All the participants were born and raised in Ogoniland, and their parents are Ogonis by birth and were all raised in Ogoniland. The participants were between junior secondary three and senior secondary. Among the junior secondary three participants, 5 came from middle class families. These participants reported that their parents attended high school; some attended Teacher's Training College

(TTC), or nursing school and 1 of them came from a low class family, the father was a standard six certificate holder and the mother had Ordinary National Diploma (OND). Among the senior secondary three participants only 1 came from high class family because the parents hold university degrees. 1 of them came from middle family the rest came from low class families. Some of these participants reported that their parents had no formal education at all and some dropped out of school because of 'yaa' and 'koo' initiation rites. The other 4 participants ( 2 males and 2 females) who had celebrated the rites of passage in Ogoniland narrated how Ogoni cultural values had impacted on their personality development. The 4 participants came from low class families, and whose parents had little or no education and who are predominantly farmers. All the participants reported that their parents use English language, Pigin- English and local languages. All the participants reported that their parents participated in the famous Ogoni cultural rite of passage into manhood and womanhood, 'yaa' and 'koo' rites. For a better understanding and better coding of information two graduate research assistants were employed.

\subsection{Data collection and analysis}

Due to the fact that much attention has not been given to the impact of cultural value system on the personality development of Ogoni teenagers, thematic analysis and broad use of grounded theory were chosen to develop an initial understanding of core issues in the sample. Grounded theory allows theories to emerge from raw data in an inductive manner while using few or no preconceived hypotheses to hinder the emergence of such theoretical prepositions (Cresswell, 1998, Glaser \& Strauss, 1967). The researcher and the two research assistants conducted interviews in a semi-structured manner and explored issues such as rites of passage into manhood and womanhood, 'sira-culture' practices, 'were-beast-affinity', masquerade-cult and how teenagers are initiated into these cultural values. At what age brackets do Ogoni initiate their children into these cultural values? Are there male or female preserve in these cultural values. What happens during the period of confinement in preparation for the rites of passage into man or woman hood and self perception.(see the appendix) The interviews which typically ranged from 45 to 90 minutes in length were recorded and carefully transcribed.

The data from the transcribed interviews were independently coded by the two research assistants including the principal researcher. This organizational method led to the formulation of a theoretical model that encompassed universal themes and concepts that emerged from all 16 qualitative interviews. The process of identifying themes started immediately after the first interview was completed and following Glaser \& Strauss's (1967) model of constant comparative methodology was modified as each subsequent interview was completed. Qualitative interview continued to be conducted until a saturation point was reached and no more new themes emerged from the interviews. To limit biases and to ensure that all possible themes were identified, explored and incorporated into the theoretical model, coding was conducted independently by the researcher and the two research assistants. They held a long discussion and some modifications were made. 


\section{Results}

3.1 Ogoni has rich cultural value systems; which is the most important and what distinguishes it from the others?

Ogoni has rich cultural value system and in Ogoniland children are initiated into the way of the life of the people at a very young age. Initial exposure to cultural values is provided by parents through child rearing practices in the home. The home is a miniature society where cultural values are incubated and disseminated. All Ogoni cultural value systems are important because each has designated impact on the personality development of the Ogonis. But the most prominent is the rite of passage into adulthood, because it is compulsory for every Ogoni person. This rite is called 'yaa' for males and 'koo' for females. It is performed between the ages of 10 to 25 years. Every Ogoni man or woman must imbibe by it, otherwise he/she does not belong to the group and will have no say in the Ogoni community, and because of its' importance, an Ogoni man can invest all he had for the 'yaa' and 'koo' initiation of his children. Most of the respondents attested that this rite of passage into manhood and womanhood is the most prominent of cultural values, and what distinguishes it from the other cultural values is because every Ogoni person is involved. They indicated that this value affects the personality development in a profound manner. The respondents reported that an Ogoniman is ready to invest more in the 'yaa' and 'koo' initiation ceremony of his children than in their western education. Respondents indicated that to change an Ogoniman' mind from 'yaa' and 'koo' initiation would mean turning the culture upside down. As the most important aspect of the cultural value system, the coming of age rites of initiation 'yaa' and 'koo' always attracts much attention. The respondents emphasized that in Ogoni traditional society there was no formal education, so the Ogoni culture did not know any other form of personality test or assessment to evaluate the intellectual, emotional, social and cognitive maturity of their adolescent children than that of passing through the initiation rites. The respondents indicated that the ceremony consists of three months' confinement in a room.

\subsection{The confinement of the 'yaa'}

The Ogoni has cultural norms that guide and direct the affairs of 'yaa' during the period of confinement.

During this period there are special duties to perform. The adolescent male does not do any farm work. His body is continuously rubbed with camwood and palm oil. He is fed on the best diet available and he is not allowed to go out into the street in the broad day light. The 'yaa' men are regarded as 'sacred' during this period. At the end of the three months' confinement, all those performing the ceremony are paraded round the town half-naked for final initiation.

The successful completion of 'yaa' accredits the male teenager as intellectually, emotionally, socially and cognitively matured and adjusted.

The respondents reported that because of the 'sacredness' of the 'yaa', some people use them as debt collectors. For instance, if a 'yaa' comes to a person's house and removes any property in lieu of a debt, he will not be challenged.

\subsection{The confinement of the 'koo'}

About the 'koo' which is the initiation of the female, it consists of three months' confinement in a fatty room.

During this confinement, the girl does not do any farm work, she does not go market, she is not seen in the day time. No man dates during this period and she is fed on the best diet available. Her visitors are limited to only those bringing her essential goods. During this period of confinement, her body is rubbed with camwood and palm oil twice daily. At the end of the confinement all the 'koo' participants are paraded through the streets of the town. They appeared naked except for a few beads tied around their waists.

After the parade the 'koo' are assembled at the main town square to entertain the audience with the rhythm of ikoni (a native musical instrument). The successful completion of the initiation ceremony attests to the intellectual, social, emotional and cognitive maturity and adjustment of the participants. Many men choose their prospective wives during the outing ceremony. 
The respondents indicated that within the periods of confinement the mentors taught the adolescents so many things inherent in their culture and other salient values. For example the 'yaa' participants are taught how to play some musical instruments like the 'geregere' (Xylophone), dancing steps of warriors and war songs or how to play massokpo (local vigilante masquerades). The 'koo' participants are taught various skills, including traditional dance with the aid of the 'geregere' played by the 'yaa' participants. They were also taught cooking, arts and crafts necessary for their womanhood. Different types of personal hygiene are taught, including the art of using clay, camwood and indigo to decorate their body as well as weaving their hairs. Most of the respondents aptly described the 'koo' as an epitome of femininity. The participants disclosed that during the period of confinement, the 'gbasugu' dance (dancing with thighs properly closed was properly taught, practiced and perfected). During the moonlight night outings these arts were conducted in the hut made of palm branches and were called 'Tor-wii'

\subsection{Cultural value and educational development in Ogoni}

The respondents unanimously attested that cultural value system in many ways affected educational development in Ogoniland. Education as an instrument of social change which gingers personality development of the people was heavily suppressed by their cultural value system. Rites of passage impacted heavily on the personality development of the 'yaa' and 'koo' members. The four adult participants cited examples of 'yaa' and 'koo' initiation impacts in their lives as follows:

\section{Pobari Said}

The 'yaa' initiation rite caused me my educational career. I was in junior secondary

class three when I went for the rite of passage I was very keen to go back to school

after my 'yaa' initiation, but at the end of the ceremony my father said that all the

monies he saved was meant for the 'yaa' initiation ceremony, that just concluded; he

had no other money for my educational pursuit.

This respondent lamented that there was nobody to help him pursue his life aspiration, so he went into canoe building and fishing and this became the means of his livelihood.

\section{Leelee Said}

I finished my primary six before I went for 'koo' initiation confinement. After the

initiation, I was not lucky to get husband during the outing. One of my uncles who

lived with a white man and who knew the importance of education sent me to

Teachers Training College (TTC); that is how I came to be where I am today,

Secondary School teacher. However I am happily married with children.

Sudor Said

I was in school when the 'yaa' initiation programme came up. My father asked me to

stop school until the initiation activities are over. After the three months'

confinement, I went back to school, but I could not catch up because the initiation

ceremony distracted me a lot. At the end of the term my results were so poor and I

was asked to repeat the class and I was ashamed to repeat. I decided to withdraw

from school and joined my father in farm works. I really regret it till today.

Saro said

I was in junior secondary class three when my father sent for me for the

koo' initiation . During the outing ceremonies I got married and when I went

back to school I did not know that I was pregnant, I was asked to withdraw

because pregnant women were not allowed to stay in school in those days.

So I left to learn how to sew. I am happily married with children.

The evidence is clear that Ogoni cultural value system impeded the educational development of the people. The respondents reported that the rigid adherence to cultural values made Ogoni division to have $5.3 \%$ literacy rate as at 1953 . The respondents disclosed that culture and tradition are the greatest enemies to modern society. The 
respondents also reported that the absence of early Christianity and western education influence in Ogoniland contributed to the mass illiteracy and rigid adherence to the dictates of culture. The respondents indicated that as at 1916 only three primary schools were established in Ogoni while other communities were ahead. Talking about the impact of cultural value system on educational and personality development of the Ogonis, one of the research assistants who was a teacher in the tertiary institution disclosed how 'yaa' initiation ceremony drastically affected his studies when he participated in that rite of passage, he said

I used to be among the first five in the class but because of the three months' confinement ceremony my class performance became poor and I felt humiliated.

The initiation ceremony distracted me a lot. Most of the respondents attested that strict adherence to cultural value system jeopardized personality as well as educational development in Ogoniland. This research assistant emphasized that it would be better if these rites of passage be taken at least after secondary school certificate examinations.

These respondents evaluated the importance of education in

the contemporary time and lamentably felt the misfortune of the adult members of

Ogoni who could not get educated. However, most indicated that the influence of education is being felt today as some of the values give way to development.

\section{5 'Sira-culture value}

'Sira'-culture value system is a value whereby one of the girls born in the family is not given out to any lawful husband. 'Sira'-cultural rite is performed for her and she becomes initiated into 'sira'-culture value. 'Sira'- culture initiation rite authorizes any girl to beget children from any she fancies. The idea is that she is helping to keep the

father's house by increasing the number of children in the family by begetting children. The respondents reported that this value is instituted where the family has many girl children and are looking for males. Or where the males are few and weak in action character wise, the girl child strongest in action character wise is initiated into 'sira' culture. The respondents disclosed that all the descendants of this woman belong to the matrilineal heritage, while those from the male belong to patrilineal. The respondents disclosed that matrilineal lineage among the Ogoni originated from 'sira'- cultural value system.

\section{Impact of 'sira'- culture on personality development}

Sira -culture has both positive and negative impacts. The positive aspect is that sira-

culture warrants a girl who would not have got a husband to beget children of her own

and have people who would inherit her property. The negative aspect is that some

girls see it as being confined under the duress of staying in their father's house

forever, thereby punctuating their emotional freedom of belonging to one man.

and the multiple choices of men might cause their life's sorrow.

There was divided opinion among the respondents denoting a mark of individual differences.

While some of the female respondents do not welcome the sira- culture practices in Ogoni tribe, some others see it as a big freedom of not being under the control of one man all their lives. However, since culture is not static, it is dynamic it may be necessary to look into some values which impinge on human personality development and reconcile the conflicting issues with reason. Some of the respondents attested that the divided opinion on sira- culture could be seen as the impact of education. In addition there is another cultural value similar to siraculture. The respondents indicated that in Ogoni tribe, if a family has an only girl child, she is not given out for marriage that attracts bride price, but any man who fancies her, goes to her parents and performs some rituals and takes her home and live like husband and wife. The children of the association bear the name of the woman's father.

\section{6 'Were-beast-affinity'}

'Were-beast-affinity' is the idea that the soul of a man or woman has the power to leave its' human form and enters into the affinity or appear in the shape of any strong animal in the bush such as the tiger, elephants, 
antelopes, tortoise and or aquatic animals such as crocodiles, turtles, catfish or hippopotamus. It is a belief by the Ogoni that taking the 'were-beast-affinity' would help them escape from dangers. Or it could be used to attack their enemies. 'Were-beast-affinity' is an evidence of anxiety about external oppressors. It is said that children belong to their mothers' affinity, the probable reason is that children feel more protected under mothers' guidance (Nwideeduh\&Dedua, 2000 in moral communication in Nwoke, 2004).

\subsection{Impact of 'were-beast-affinity' on personality development}

It is a general belief by the Ogonis that since they are oppressed by their neighbours attaching to such powerful beast through affinity would act as a buffer in their security.

\subsection{Masquerade cult-value}

Ogoni traditional masquerade cult-value has remained inviolable.

Masquerade cult- value commands respect and wield unequalled power among the

Ogoni. One of the parameter for eligibility for initiation into masquerade cult is the ability of the person to keep to the dictates of the cult. The most powerful of Ogoni masquerade is called 'Mossokpu'. It serves as vigilante in the community. It is believed that its' activities are shrouded in mystery, and therefore it is consulted in settling land disputes between people as well as social problems. Ogoni masquerade cult is used as a powerful weapon and warrior against external forces.

\subsection{Impact of masquerade on personality development}
Youngsters evaluate their strength as they forcefully capture offenders. They also
display their physical dexterity through acrobatic exercise of masquerade.

\section{Discussion}

Based on the findings of this present study, Ogoni has very rich cultural value system and all these values have significant impacts on the personality development of Ogoni adolescents. The present study revealed that prominent among the values is the rite of passage into adulthood, which every Ogoni man or woman is obliged to perform at designated periods. The initiation rite of passage into manhood is called 'yaa' and that of womanhood is called 'koo' This study revealed that in Ogoniland the rite of passage into adulthood attracts more public attention than any other values and an Ogoniman is ready to invest a treasure in the 'yaa' and 'koo' of his children. This finding seem to support Gbenenye (1998), who observed that in Ogoni tribe 'yaa' and 'koo' are cultural rites of initiation into manhood and womanhood and Ogoni man is ready to spend more treasures in the 'yaa' and 'koo' initiation ceremony of his children than in their western education. To buttress this assertion, Nwideeduh (1998), observed that to change an Ogoni man's mind from 'yaa' and 'koo' initiation would mean turning the culture upside down or to obliterate the culture from the universe. The findings of this study resealed that in Ogoni traditional society, there was no formal education and their only form of personality test or assessment in terms of intellectual, social, cognitive and emotional stability was only by the accomplishing the ordeals of 'yaa' and'koo' rite initiation.

\subsection{During the three months confinement}

Based on the current findings, the participants of 'yaa' and 'koo' passage rites are confined in a secluded room for three months. The report obtained in this study showed that the 'yaa' males are kept separately with masters in charge of them. The 'koo' females are kept in a separate room with mistresses in charge of them; with each group teaching the adolescents some innate salient values in the culture. On this ground one of the respondents Pobari indicated that it may take a researcher a hundred years to capture or unravel all the things the adolescents were taught when they were confined. This present finding supports (Lolo,1981, Nwideeduh, 1998; Nwoke 2004), who observed that because of the deep spirituality to which the 'yaa' men are subjected to during the period of confinement, they are termed 'sacred' and they command respect.

\subsection{Reasons for the attachment to value systems}

The present study revealed that before the advent of Christianity and colonial administration, the Ogonis strongly belief in life after death, in order words, there was a strong belief that if one lived a worthless and profane life on earth, the same would be one's experience in death after this life. This finding supports (Andahs, 1994) who observed that for the Ogonis a man must always be a man alive or dead. The findings of this current study emphatically buttress the reasons for all the traditional initiations, sacrifices to gods and goddesses, and strong 
attachment to 'were-beast-affinity'; all aspects of spiritual purifications and strengthening of the body. For example this present study revealed that the 'yaa' ritual ceremony conferred on the performer prerogative or privilege of crowning the village head as well as performing some rituals base on the tenets of the worship of their ancestors. To further buttress this assertion Gbenenye (1988, Kpone-Tonwe, 1992) observed that it was in the direction of performing rituals that some well fortified elders acquired the 'Gbene' title, which enabled an individual to become a possessing ancestral spirit to be worshiped as god by the people.

The present study revealed that it was a general practice in Ogoniland for most men to initiate their sons into 'yaa' rituals at the expense of their education because the tenet is that the sons coming after them should be adequately fortified spiritually to enable them discharge their traditional responsibilities successfully without any psychic attacks.

This current study also disclosed that a father who knows that his daughter would observe purda may consider the money he would spend in giving her proper education as a waste. It is no wonder then, that the 'yaa' and'koo' initiation attracts a lot of public attention and all the idiosyncrasies attached to the ceremony.

The findings of this present study show that the Ogonis still attach much importance to their cultural value system. To buttress this assertion, Joshua(2009) observe that despite the influence of Christianity, modernity and education, many aspects of the indigenous Ogoni culture and religion are till date evident. The land on which they live, the rivers that surround them are very important to Ogoni people, that they not only provide enough food, they are also believed to be a god and are worshiped as such. The planting and harvesting periods especially yam in Ogoni is laden with spiritual, religious and social activities. The current findings show that Ogoni believe that the soul of human being has the ability to leave its' human form to take the form of a beast in what is called 'were-beast- affinity'

\subsection{Understanding the 'sira' culture}

The findings of this present study revealed that Ogoni practice 'sira' culture, a title taken only by the females. The present study indicated that in Ogoniland, if a family has few male children, the family would initiate one of the girl children into 'sira' -culture. This value system warrants the girl to beget children from any man she fancies. Based on the present finding the idea is that she would beget children to make up the shortfall of male children in her father's family. The finding of this current study revealed that 'sira' value is appreciated by most females who strongly adhere to it, while few females dislike it. This finding supports Nwideeduh $(1975,1998)$ who emphasizing the benefits of this value among Ogoni females stated that 'to change an Ogoni woman's mind from 'sira'-culture would mean erasing Ogoni female folk from Ogoni tribe' To buttress this assertion Alagoa (1972) attested that 'sira' culture is the origin of matrilineal linage which warrants the woman's descendants to inherit her property.

\subsection{Understanding the 'were-beast-affinity and masquerade-cult}

The findings of this present study revealed that Ogoni was totally cut off from the outside world and its' influence for a very long period and this made her adhere to value systems especially 'were-beast-affinity' and masquerade cult. This finding supports Kpene-Tonwe (1990) who observed that Ogonis were glued to their environment and culture that they had reasons to resist the British Colonial forces which invaded Ogoni territory and established foothold at the nearest neighbourhood the Kono in 1901. In further support of these findings, Obi (1997) observed that till today the Ogonis make a formidable force against any external forces or oppressors, for example the Ogoni drove away the Shell B.P. Oil Company form their land. The present study disclosed that the masquerade cult is the Ogoni's major local vigilante guard. Given to the findings of this current study, supported by the findings of other studies cited here it became evident that cultural value system made a lot of impact on the personality development of the Ogonis.

\subsection{Understanding the impact of education on Ogoni culture}

Based on the findings of this present study, education has influenced some part of Ogoni cultural value system, by opening some avenues for development. To support these findings Nwideeduh (1998, Gbenenye, 1998) observed that the high illiteracy rate of Ogoni seems to be a thing of the past, that the introduction of western education has brought some social change and enlightenment in Ogoniland. But the findings suggest that its' impact is not fully felt among the population it is still on the periphery in terms of capital development in Ogoniland. Ibeanu (2008) supports this finding when he stated that, even though Ogoni seem to be influenced by western education, more proficiency is needed to extricate Ogoni tribe from the clutches of marginalization and grip of poverty through their professionalism. To buttress this finding still Wami (2006) observed that though 
there is a little influence of educational development, yet more trained skilful personalities are needed to tap Ogoni natural resources.

\section{Conclusions}

This qualitative study, the first of its' kind has shed light on the impact of cultural value system on the personality development of Ogoni adolescents. These adolescents undergo serious cultural value rites of initiation. An understanding of these cultural value systems and their impacts on the personality of the Ogoni is crucial in order to better serve this population in therapeutic or clinical settings.

\section{Limitation}

While the findings of this present study are certainly informative, certain limitations must be taken into consideration. Due to snowballing sampling technique used, the participants came almost from the same locality. When interpreting these findings, it is important to note that this saple came from low, not well-educated family background, may distinguish these adolescents from other adolescents who came from well- educated and high class families. These findings may be indicative of the experiences of this particular locality; however, it may not be reflective of other adolescents in Ogoni entire group. Without replication studies, it is quite unclear whether the findings of this present study are representative of adolescents in the whole of Ogoni tribe or only this particular community.

Furthermore culture is not static, so also the value systems. While the cross-sectional data collected provides a glimpse of what these adolescents are going through at a given point in their lives, it may not be able to capture the full experience of growing up in Ogoniland. A follow- up longitudinal study would be able to further expand on the findings of this current study.

\section{References}

Akassa. (1998). Community development project (ACAP) Bayelsa fact files on forest.

Alagoa, E.J. (1972). A Short story of the Niger Delta. Ibadan: Longmans.

Andah, B.M. (1982). African development in cultural perspective. Ibadan University Press.

Andah, B.M. (1988). African anthropology. Ibadan: Shameson Ltd.

Chukwuagguh, C.C. (1998). Culture and its development through time: The African indigenous experience, Afe. Journal of Minorities Studies, 2, 92-97.

Cresswell, J.W. (1998). Qualitative inquiry and research design. Thousand Oaks. CA: Sage.

Dibiah, G.O. (1988). The Eleme chieftaincy institution in transition. Unpublished B.A. Thesis, University of Port-Harcourt.

Egonwa, O.D. (1994). African art. A contemporary source book. Benin: Osasu, Publishers.

Ephraim, G. (1994). the place of firstborn children in traditional Ekpeye belief Owu. Port-Harcourt: Journal of Humanistic Studies, 1 (1): 103 -111.

Gbenenye, E.M. (1998). A Political history of Ogoni from early time to 1960. Unpublished M.A. Thesis, University of Port-Harcourt.

Glaser,B.G. \& Strauss, A.L. (1967). The discovery of grounded theory: Strategies for qualitative research. NY: Adline

Haralambos, M. \& Heald, R. (1980). Sociology themes \& perspectives. Great Britain: Richard Clay.

Haviland, W.A. (1983). Cultural anthropology. New York: Hort, Rinehard and Winston.

Ibeanu, O.O. (2008). Affluence and affiliation. The Niger Delta as a critique of Political Science in Nigeria. An Inaugural Lecture of the University of Nigeria, Nsukka.

Joshua, Project. (2009). Ogoni of Nigeria ethnic people profile. Online.

Kpone-Tonwe, S. (1990). The Ogoni of the eastern Niger Delta mainland. An economic and political history from the earliest times to about 1900. Unpublished Ph.D. Dissertation University of Port-Harcourt.

Kpone-Tonwe, S. (1992). The Gbene title and ancestral worship in Ogoni. Paper presented at the first Niger Delta studies conference held at the Institute of Foundation Studies, Rivers State. University of Science and Technology. Nkpolu Port-Harcourt. $7^{\text {th }}-10^{\text {th }}$ April.

Loolo, G.N. (1981). A history of Ogoni. Port-Harcourt: NP. 
Mbiti, J.S. (1969). African religions and Philosophy. London: Heinemann.

Mbiti, J.S. (1980). African religion and philosophy London: Heinemann. Educational Books.

Nwideeduh, S.B. (1975). The impact of culture on the life styles of the Khana tribe of Nigeria. Unpublished Research, paper.

Nwideeduh, S.B. (1989). A critical analysis of culture dynamics in Ogoni. A paper presented at a seminar under the auspices of Ogoni central union, Bori August, 25.

Nwideeduh, S.B. (1998). Cultural differentiation and educational disparity in Nigeria. The case of Ogoni. Afe. Journal of Minorities Studies, 2, 7-18.

Nwoke, M.B. (2004). The effects of ethnic group, age and gender differences on the bio-socio-cognitive adjustment of teenagers. Unpublished Ph.D. Thesis, University of Nigeria, Nsukka.

Obi, C. (1997). Globalisation and local resistance: The case of the Ogoni versus Shell. New Political Economy, 2(1):137. http://dx.doi.org/10.1080/13563469708406291

Okorosaye-Oribite, A.K. (1990). Factors responsible for educational underdevelopment in Rivers State. A historical perspective. Unpublished Ph.D. Dissertation, University of Port-Harcourt.

Phinney, J.S. \& Alipura, L.L. (1990). Ethnic identity in college students from four ethnic groups. Journal of Adolescence, 13, 171-183. http://dx.doi.org/10.1016/0140-1971(90)90006-S

Santrock, J.W. (2006). Life-span development $\left(10^{\text {th }}\right.$. Ed). New York: McGraw-Hill Companies, Inc.

Schrest, L. \& Wallace, J. (1967). Psychology and human problems. Columbus: Ohio-Charles E, Merril Publishing Co.

This Day Newspaper Publication. (2005).

UNPO. (1995). Ogoni: report of the UNPO mission to investigate the situation of the Ogoni of Nigeria, February 17-26.

Wami, E.N. (2006). Gas Flaring: wealth in flames. Inaugural lecture series No. 21. Rivers State University of Science and Technology, Port-Harcourt.

Wegh, S.F. (1994). Marriage, family and church in Tiv. Makurdi Dekon Computer Services.

\section{Appendix A}

Semi-structured Interview exploring the impact of cultural value system on the personality

development of Ogoni adolescents.

Tell me a little about yourself.

Do you identify with Ogoni cultural value system?

What does it mean to you to identify with Ogoni cultural values?

What impact does the initiation have in your life?

Does anything bother you about Ogoni cultural value system?

\section{Ogoni has a lot of cultural value systems}

How do you deal with these cultural values?

Which cultural value system is the most important?

What distinguishes it from the other values?

What happens during the initiation rites of passage?

What do you learn about rites of passage?

Are there groups of people or places that help get you initiated?

Are there any activities you do to mark your initiation?

In Ogoniland do males and females go through the same rites of passage initiation?

Do you have different rite's names of initiation for each gender?

For the rites of passage into manhood and womanhood the participants are confined

for a period of time

For how long are they confined? 
Are the males and females kept together during this period of confinement?

Do the participants learn anything during the period of confinement?

\section{What is 'sira' cultural value?}

Is it a title, and who takes it?

How does a person who takes this title feel?

Has 'sira' culture any impact on the holder?

Is the 'sira' cultural value still in practice?

Is there cultural value similar to 'sira' culture?

Is there any side effect of 'sira' culture?

\section{What is 'were beast affinity'?}

How do you assess 'were beast affinity'?

Whose affinity do you go after, your father's or mother's?

\section{What is masquerade cult value?}

*Who goes into masquerade cult value and at what age?

*Do you have anything else you will like to tell me, that will help me understand Ogoni

cultural value system better?

Generally, how do you see or perceive your cultural value system?

Table 1. A table showing the demographics of the participants

\begin{tabular}{|c|c|c|c|c|c|c|c|}
\hline Name & Age & $\begin{array}{l}\text { Location of } \\
\text { school }\end{array}$ & Gender & $\begin{array}{l}\text { Level of } \\
\text { study }\end{array}$ & $\begin{array}{l}\text { Socio-economic } \\
\text { status }\end{array}$ & $\begin{array}{l}\text { Mother's } \\
\text { educational } \\
\text { level }\end{array}$ & $\begin{array}{l}\text { Father's } \\
\text { educational } \\
\text { level }\end{array}$ \\
\hline Kabari & 13 & $\begin{array}{l}\text { Bodo Boys' } \\
\text { secondary sch. }\end{array}$ & $\mathrm{M}$ & JSS 3 & Middle class & High school & $\begin{array}{l}\text { Class } \\
\text { teacher }\end{array}$ \\
\hline Barisua & 14 & $\begin{array}{l}\text { Bori Boys' } \\
\text { secondary sch. }\end{array}$ & $\mathrm{M}$ & JSS3 & Middle class & $\begin{array}{l}\text { Secondary } \\
\text { sch. }\end{array}$ & High school \\
\hline Dedua & 15 & $\begin{array}{l}\text { Bane Girls' } \\
\text { secondary sch. }\end{array}$ & $\mathrm{F}$ & JSS 3 & Low class & Standard six & TTC \\
\hline Barida & 15 & $\begin{array}{l}\text { Buna.com } \\
\text { secondary sch. }\end{array}$ & $\bar{F}$ & JSS3 & Middle & High School & Diploma \\
\hline Dumle & 15 & $\begin{array}{l}\text { Kporiri Govent } \\
\text { secondary sch. }\end{array}$ & $\mathrm{M}$ & JSS 3 & Middle & High school & High sch \\
\hline Suka & 13 & Bane Com Sch & $\mathrm{F}$ & JSS3 & Low & $\begin{array}{l}\text { NO } \\
\text { education }\end{array}$ & $\begin{array}{l}\text { NO } \\
\text { education }\end{array}$ \\
\hline Sabari & 16 & $\begin{array}{ll}\text { Nonwa } & \text { Com. } \\
\text { School } & \end{array}$ & $\mathrm{F}$ & SS3 & Low class & Standard 4 & Standard 4 \\
\hline Kale & 17 & G.T.C Bodo & $\mathrm{M}$ & SS3 & Low class & $\begin{array}{l}\text { No } \\
\text { education }\end{array}$ & Primary 6 \\
\hline Nwinee & 18 & G.T.C Kpor & $\mathrm{M}$ & SS 3 & Low class & Standard 6 & TTC \\
\hline Dumlaka & 18 & Girls'Sch Bane & $\mathrm{F}$ & SS 3 & High class & Graduate & Graduate \\
\hline Barisi & 17 & $\begin{array}{l}\text { Nonwa } \\
\text { school }\end{array}$ & $\mathrm{F}$ & SS 3 & Middle & High school & Nursing \\
\hline Fiito & 16 & Birabi sch Bori & $\mathrm{M}$ & SS 3 & Low class & Primary six & Primary 4 \\
\hline Sudor & 20 & Farmer & $\mathrm{M}$ & $\begin{array}{l}\text { Dropped } \\
\text { out }\end{array}$ & Low class & $\begin{array}{l}\text { No } \\
\text { education }\end{array}$ & Farmer \\
\hline Leelee & 23 & Class teacher & $\mathrm{F}$ & TTC & Low class & $\begin{array}{l}\text { No } \\
\text { education }\end{array}$ & Farmer \\
\hline Pobari & 25 & Builder & $\mathrm{M}$ & $\begin{array}{l}\text { Dropped } \\
\text { out }\end{array}$ & Low class & Trader & Farmer \\
\hline Saro & 25 & Seamstress & $\mathrm{F}$ & $\begin{array}{l}\text { Dropped } \\
\text { out }\end{array}$ & Low class & Seamstress & Farmer \\
\hline
\end{tabular}

